\title{
Выделение изоферментов сукцинатдегидрогеназы из листьев гороха методом ионообменной хроматографии
}

\author{
Федорин Д.Н., Епринцев А.Т. \\ ФГБОУ ВО «Воронежский государственный университет», Воронеж
}

Поступила в редакцию 8.05.2018 г.

DOI: https://doi.org/10.17308/sorpchrom.2018.18/564

Применение ионообменной хроматографии на колонке с ДЭАЭ-целлюлозой позволило получить высокоочищенные препараты сукцинатдегидрогеназы (СДГ, КФ 1.3.99.1) из листьев гороха с удельной активностью 1,665 Е/мг белка (для первой формы) и 0,445 Е/мг белка (для второй формы); выходом $22.48 \%$ и $14.99 \%$. Степень очистки для изоферментов СДГ составила 79.29 и 21.19 раза соответственно. Показано, что полученные препараты сукцинатдегидрогеназы десорбировались с ДЭАЭ-целлюлозы при концентрациях хлорида калия 85 и 95 мМ, соответственно.

Ключевые слова: сукцинатдегидрогеназа, изоформы, ионообменная хроматография, электрофорез, горох.

\section{Isolation of isoenzymes succinate dehydrogenase from pea leaves by ion exchange chromatography}

\author{
Fedorin D.N., Eprintsev A.T. \\ Voronezh State University, Voronezh
}

Succinate dehydrogenase (SDH) is a multifunctional enzyme and for this reason has an almost universal distribution among living organisms. This enzyme plays a key role in the regulation of aerobic respiration. In addition, SDH is a membrane-bound enzyme, which determines its polyfunctionality - participation in the functioning of the TCA and the operation of the electron transport chain (complex II). Despite the large amount of experimental material on the physicochemical and regulatory characteristics of succinate dehydrogenase from objects of various origins, methods of regulating the activity of this enzyme system in plants under conditions of changing environmental factors remain unknown or poorly studied.

The preparation of highly purified SDH preparations from the leaves was done by a 4-stage purification method. An important stage, which allowed to separate the separate forms of the enzyme, was the stage of ion-exchange chromatography. Desorption with a linear gradient of potassium chloride within the range of 50-125 mM made it possible to separate the individual forms of the enzyme under study in a highly purified state. The obtained preparations of succinate dehydrogenase isoforms will allow further study of their regulatory and kinetic properties in order to establish mechanisms of regulation of the intensity of oxidative and constructive metabolism at the level of succinate dehydrogenase.

\section{Введение}

Сукцинатдегидрогеназа (КФ 1.3.99.1) является функциональной частью одновременно ЦТК и аэробной дыхательной цепи, катализируя окисление сукцината до фумарата и восстановление убихинона до убихинола. Этот фермент состоит из че- 
тырех субъединиц: субъединицы A - флавопротеина, субъединицы B - Fe-S-белка, субъединицы C и субъединицы Д - двух маленьких интегральных мембранных белков, содержащих цитохром b-обогащенную фракцию [1]. Сукцинат-связывающий сайт сформирован субъединицей А, с которой ковалентно связан флавинадениннуклеотид, являющийся акцептором ионов $\mathrm{H}^{+}$при окислении сукцината. Генетическая детерминация СДГ в геномах различных организмов обусловлена наличием полигенного семейства. Известно, что в геноме модельного объекта Arabidopsis thaliana субъединица А кодируется двумя генами - $s d h 1-1, s d h 1-2$, субъединица В - тремя $s d h 2-1, s d h 2-2, s d h 2-3$, субъединица С - двумя - $s d h 3-1$ и $s d h 3-2$, субъединица Д - одним $-s d h 4[2]$.

Важным для создания целостной картины метаболических процессов и механизмов их регуляции при изменении условий внешней среды является изучение механизмов контроля активности сукцинатдегидрогеназы, как связующего звена двух важных для клетки процессов - цикла Кребса и электронтранспортной цепи митохондрий. В частности, исследование кинетических и регуляторных характеристик молекулярных форм исследуемого фермента позволяет определить функциональную роль каждого из них в обеспечении метаболических потоков клетки в зависимости от ее потребности в энергии и биосинтетических субстратах. Подобные исследования проводятся на очищенных препаратах сукцинатдегидрогеназы, которые ранее были получены из ряда объектов [3, 4]. В связи с этим целью работы явилось получение высокоочищенных препаратов изоферментов сукцинатдегидрогеназы из листьев гороха с помощью многостадийной очистки, включающей ионообменную хроматографию.

\section{Эксперимент}

В качестве объекта исследования использовали 22-дневные растения гороха (Pisum sativum L.), выращенные гидропонными способом при 12-часовом световом дне и интенсивности 25 Дж/ $/ \mathrm{M}^{2}$.

Активность СДГ определяли в листьях гороха на спектрофотометре СФ-2000 (ОКБ «Спектр», Россия). Активность фермента рассчитывали по падению оптической плотности среды при длине волны 600 нм, обусловленному обесцвечиванием 2,6-дихлорфенолиндофенола в ходе его восстановления [5]. За единицу ферментативной активности принимали количество фермента, образующего 1 мкмоль продукта за 1 мин при $25^{\circ} \mathrm{C}$.

Очистку фермента осуществляли в несколько стадий при температуре $0-4^{\circ} \mathrm{C}$. Стадия 1. Гомогенизация. Навеску растительного материала (3г) гомогенизировали в соотношении 1:5 со средой выделения следующего состава: 50 мМ Трис-HCl буфер (pH 7.5), содержащий 1 мМ ЭДТА, 10 мM KCl, 1 мM MgCl. Стадия 2. Полученный гомогенат фильтровали через 4 слоя марли и центрифугировали в течение 5 мин. при $3000 \mathrm{~g}$. Надосадочную жидкость фракционировали сульфатом аммония с последующей гель-фильтрацией на колонке с сефадексом G-25. К супернатанту добавляли кристаллический сульфат аммония до $20 \%$ насыщения и центрифугировали 20 мин. при $15000 \mathrm{~g}$. Супернатант вновь фракционировали до 60\% насыщения сульфатом аммония и вновь центрифугировали 20 мин. при $15000 \mathrm{~g}$. Осадок ресуспендировали в 1-2 мл среды, содержащей 10 мМ фосфатный буфер (pH 7.8), 0,01\% тритон X-100, 20 мМ сукцинат натрия. Полученный ферментативный препарат наносили на колонку, заполненную сефадексом G-25 для освобождения от низкомолекулярных примесей. Элюцию осуществляли 10 мМ фосфатным буфером (pH 7.8), содержащим 20 мМ сукцинат натрия, со скоростью 15-20 мл в час. Стадия 
4. Ионообменная хроматография. Фермент наносили на колонку с ДЭАЭцеллюлозой, предварительно уравновешенную 30мМ фосфатным буфером (pH 7.8), содержащим $30 \mathrm{MM} \mathrm{KCl} \mathrm{[6,7].} \mathrm{Фракции} \mathrm{собирали} \mathrm{вручную} \mathrm{по} 1$ мл в градуированные микропробирки Eppendorf. Фермент десорбировали с колонки градиентом концентрации $\mathrm{KCl}$ в среде элюирования. Наиболее оптимальным для десорбции фермента был линейный градиент концентрации $\mathrm{KCl}$ от 0.05 до $0.125 \mathrm{M}$, среда десорбирования представляла собой 20 мМ фосфатный буфер (pH 6.2), содержащий 20 мМ сукцината. Активность фермента обнаруживалась под действием ионной силы раствора в среде элюирования, достаточной для отрыва сукцинатдегидрогеназы от ДЭАЭ-целлюлозы.

Полученные данные обрабатывали с использованием статистических критериев. Обсуждаются статистически достоверные различия при $\mathrm{p}<0.05$ [8].

\section{Обсуждение результатов}

Получение высокоочищенных препаратов СДГ из листьев гороха проводили методом 4-х стадийной очистки. Результаты типичной очистки представлены в таблице 1.

Таблица 1. Очистка сукцинатдегидрогеназы из листьев гороха $(\mathrm{n}=3, \mathrm{p}<0.05)$

\begin{tabular}{|c|c|c|c|c|c|c|}
\hline Стадия & $\begin{array}{c}\text { Объем } \\
\text { фракций, } \\
\text { см }^{3}\end{array}$ & $\begin{array}{c}\text { Количество } \\
\text { белка, мг }\end{array}$ & $\begin{array}{c}\text { Общая ак- } \\
\text { тивность, } \\
\text { Е }\end{array}$ & $\begin{array}{c}\text { Удельная ак- } \\
\text { тивность, } \\
\text { Е/мг белка }\end{array}$ & $\begin{array}{c}\text { Выход } \\
\%\end{array}$ & $\begin{array}{l}\text { Степень } \\
\text { очистки }\end{array}$ \\
\hline Гомогенизация & 8 & 60.72 & 1.281 & 0.021 & 100 & 1 \\
\hline $\begin{array}{c}\text { Фракционирование } \\
\text { сульфатом аммо- } \\
\text { ния } 20-80 \%\end{array}$ & 4 & 5.98 & 1.024 & 0.171 & 79.94 & 8.14 \\
\hline $\begin{array}{c}\text { Гель-фильтрация на } \\
\text { сефадексе G-25 }\end{array}$ & 7.4 & 4.03 & 0.947 & 0.235 & 73.93 & 11.19 \\
\hline Хроматография на & 1) & 0.173 & 0.288 & 1.665 & 22.48 & 79.29 \\
\hline ДЭАЭ-целлюлозе & 2) & 0.431 & 0.192 & 0.445 & 14.99 & 21.19 \\
\hline
\end{tabular}

Выход рассчитывался как доля (\%) активности сукцинатдегидрогеназы на данной стадии от активности фермента в гомогенате, которая принимается за 100\%. Степень очистки рассчитывалась как отношение удельной активности сукцинатдегидрогеназы на данной стадии к удельной активности фермента в гомогенате.

Экстракцию фермента из растительного материала проводили в среде выделения без сахарозы для экстракции всех форм исследуемого фермента растительной клетки. Удельная активность фермента на данном этапе составила 0.021 Е/мг белка.

Фракционирование полученного экстракта сульфатом аммония в пределах насыщения 20-80\% позволило очистить препарат сукцинатдегидрогеназы в 8.14 раза, удельная активность при этом составила $0.171 \mathrm{E} /$ мг белка.

Важным этапом очистки фермента из листьев гороха являлась стадия ионообменной хроматографии на ДЭАЭ-целлюлозе. Элюцию фермента с колонки осуществляли линейным градиентом хлорида калия от 50 до 125 мМ и содержанием сукцината в среде 20 мМ. После стадии ионообменной хроматографии на ДЭАЭцеллюлозе сукцинатдегидрогеназа из листьев гороха была очищена с разной степенью для каждой из фракций. СДГ1 имеет удельную активность 1.665 Е/мг белка, при 
этом степень очистки составила 79.29 раз с выходом 22.48\%. Для СДГ2 удельная активность составила 0.445 Е/мг белка, степень очистки 21.19 раза и выходом $14.99 \%$. Применение четырехстадийной очистки позволило получить высокоочищенные препараты сукцинатдегидрогеназы из листьев гороха с высокими показателями удельной активности и выходом фермента.

Таким образом, была разработана эффективная схема очистки СДГ из листьев гороха, включающая ионообменную хроматографию как основную стадию разделения изоформ. Аналогичные результаты ранее были получены для изоферментов из листьев кукурузы, где определяющей стадией очистки также являлась ионообменная хроматография [9]. Полученные в ходе очистки высокоочищенные препараты изоформ сукцинатдегидрогеназы позволяют в дальнейшем изучить их регуляторные и кинетические свойства с целью установления механизмов регуляции интенсивности окислительного и конструктивного метаболизма на уровне сукцинатдегидрогеназы.

Анализ профиля элюции изоферментов сукцинатдегидрогеназы с колонки ДЭАЭ-целлюлозы показал, что данные белки имеют различную степень сорбции на данном носителе. Поскольку фермент заряжен отрицательно, а колонка положительно, между ними возникает электростатическое взаимодействие. Чем сильнее заряжен белок, тем сильнее его взаимодействие с сорбентом. Разделение белков происходит путем десорбции их с носителя раствором, ионной силы которого достаточно для разрыва электростатических связей фермента и сорбента. Результаты исследования показали, что первая форма СДГ1 десорбируется с колонки с ДЭАЭ-целлюлозой при концентрации $\mathrm{KCl} 85$ мМ, в то время как СДГ при 95 мМ (рис. 1). Следовательно, данные изоферменты имеют различие в поверхностном заряде белковых молекул.

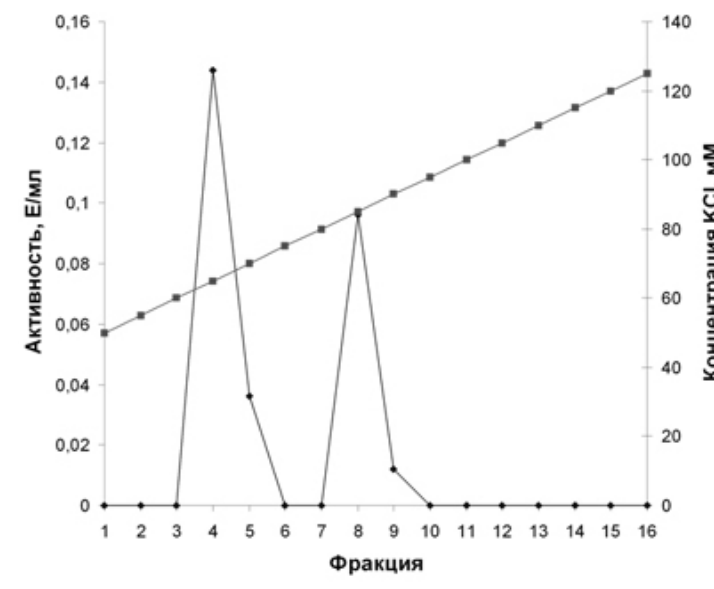

a

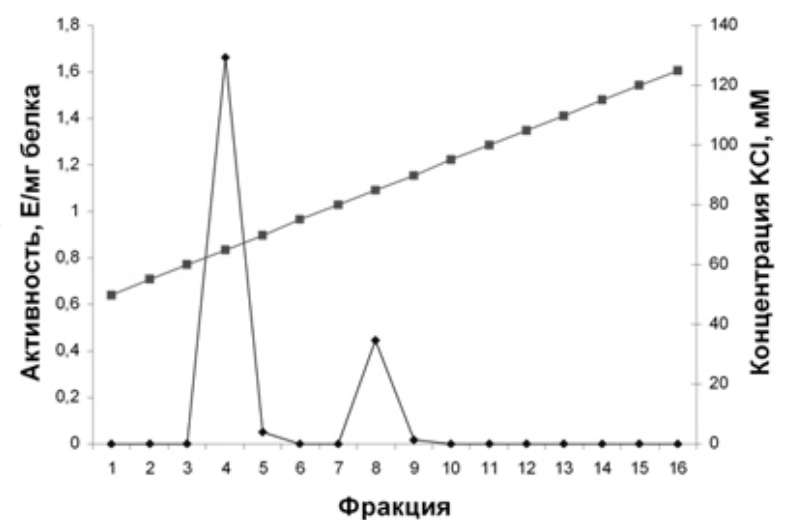

б

Рис. 1. Профиль элюции с колонки ДЕАЕ-целлюлозы изоферментов сукцинатдегидрогеназы из листьев гороха. А - общая активность. Б - удельная активность.

\section{Заключение}

Таким образом, был разработан эффективный способ очистки СДГ из листьев гороха, включающий ионообменную хроматографию на ДЭАЭ-целлюлозе. В качестве определяющей стадии очистки осуществляли ионообменную хроматографию, позволившую получить две формы исследуемого фермента в высокоочищенном состоянии. Показано, что все формы СДГ десорбируются с ДЭАЭ-целлюлозы при разных концентрациях хлорида калия, что может указывать на различие в структурной организации полипептидных компонентов изоформ сукцинатдегидрогеназы. 
Полученные препараты сукцинатдегидрогеназы позволяют изучить влияние факторов разной природы для выявления механизмов регуляции исследуемого ферментного комплекса на уровне метаболитов клетки и ионного состава среды.

Работа выполнена при финансовой поддержке Российского научного фонда (РНФ, грант №14-14-00721).

\section{Список литературы}

1. Figueroa P., Leon G., Elorza A., Holuigue L. et al. // Plant molecular biology. 2002. Vol. 50. pp. 725-734.

2. Figueroa P. // Plant. Mol. Biol. 2001. Vol. 46. pp. 241-250.

3. Федорин Д.Н., Карабутова Л.А., Флорес К., Епринцев А.Т. // Сорбиионные и хроматографические прочессы. 2017. Т. 17. № 5. C. 818-823.

4. Oyedotun K.S., Lemire B.D. // J. Biol. Chem. 2004. Vol. 279. pp. 9424-9431.

5. Попов В.Н., Епринцев А.Т., Федорин Д.Н. // Физиология растений. Т. 54. 2007. № 3. C. 409-415.

\section{References}

1. Figueroa P., Leon G., Elorza A., Holuigue L. et al., Plant molekulyarnaya biologiya, 2002, Vol. 50, pp. 725-734.

2. Figeroa P., Zavod. Mol. Biol., 2001, Vol. 46, pp. 241-250.

3. Fedorin D.N., Karabutova L.A., Flores K., Yeprintsev A.T., Sorbtsionnyye i khromatograficheskiye protsessy, 2017, Vol. 17, No 5, pp. 818-823.

4. Oyedotun K.S., Lemire B.D., J. Biol. Khimreagent, 2004, Vol. 279, pp. 9424-9431.

5. Popov V.N., Yeprintsev A.T., Fedorin D.N., Fiziologiya rasteniy, 2007, Vol. 54, No 3, pp. 409-415.

Федорин Дмитрий Николаевич - к.б.н., кафедра биохимии и физиологии клетки, Воронежский государственный университет, Воронеж, тел.(473)2208877

Епринцев Александр Трофимович - д.б.н., проф., кафедра биохимии и физиологии клетки, Воронежский государственный университет, Воронеж, тел.(473)2208877
6. Karpov S.I., Matveeva M.V., Selemenev V.F. // Russian Journal of Physical Chemistry A. 2001. Vol. 75. No 2. pp. 266-271.

7. Селеменев В.Ф., Рудаков О.Б., Славинская Г.В., Дроздова Н.В. Пигменты пищевых производств (меланоидины). М. ДеЛи принт. 2008. $246 \mathrm{c}$.

8. Лакин Г.Ф. Биометрия. М. Высш. шк. 1990. 351c.

9. Федорин Д.Н., Карабутова Л.А., Покусина Т.А., Епринцев А.Т. // Сорбиионные и хроматографические проиессы. 2016 Т. 16. № 4. C. $280-285$.

6. Karpov S.I., Matveyeva M.V., Selemenev V.F., Rossiyskiy zhurnal fizicheskoy khimii, Vol. 75, No 2, pp. 266-271.

7. Selemenev V.F., Rudakov O.B., Slavinskaya G.V., Drozdeva N.V. M., DeLi print, 2008, 246 p.

8. Lakin G.F. Biometriya. M., Vyssh. shk., 1990, 351p.

9. Fedorin D.N., Karabutova L.A., Pokusina T.A., Yeprintsev A.T., Sorbtsionnyye i khromatograficheskiye protsessy, 2016, Vol. 16, No 4, pp. 280-285.

Fedorin Dmitry Nicolaievich - Ph.D of Biology, Department of Biochemistry and Physiology, Voronezh State University, Voronezh, e-mail: rybolov@mail.ru,

Eprintsev Alexander Trofimovich - Doctor of Biology, Department of Biochemistry and Physiology, Voronezh State University, Voronezh, email: bc366@bio.vsu.ru 